\title{
PERTANGGUNGJAWABAN PIDANA TERHADAP PELAKU ABORTUS PROVOCATUS CRIMINALIS (TINDAK PIDANA ABORSI)
}

\author{
Oleh : \\ Rini Wulandari \\ Email : riniwul20@gmail.com \\ Universitas Narotama Surabaya
}

\begin{abstract}
Abstrak
Aborsi adalah aborsi, pelepasan hasil konsepsi atau pembuahan sebelum waktunya. Kehilangan janin yang tidak disengaja biasanya terjadi pada kehamilan muda (satu sampai tiga bulan). Terkadang kehamilan seorang wanita bisa mati dengan sendirinya tanpa tindakan atau tindakan yang disengaja. Ini sering disebut sebagai "keguguran" atau aborsi spontan. Ini sering terjadi pada ibu yang masih hamil, karena hasil yang tidak disengaja dan diinginkan atau karena penyakit. Jika aborsi karena pemerkosaan dijadikan pengecualian sebagai alasan medis, maka kriteria yang digunakan sebagai pengecualian harus benarbenar jelas dan tegas. , sehingga tidak disalahgunakan oleh orang yang tidak bertanggung jawab, akibatnya aborsi marak. Mengenai ancaman sanksi pidana bagi pelaku aborsi provocatus, dalam hukum pidana (KUHP) dirumuskan bahwa ada ancaman pidana bagi mereka yang melakukan aborsi. KUHP tidak peduli dengan latar belakang atau alasan aborsi.
\end{abstract}

Kata Kunci: aborsi, alasan medis, hukum

\begin{abstract}
Abortion is abortion, the release of the results of conception or fertilization prematurely. Unintentional fetal loss usually occurs in young pregnancies (one to three months). Sometimes a woman's pregnancy can die on its own without an act or intentional act. This is often referred to as "miscarriage" or spontaneous abortion. This often happens to mothers who are still pregnant, due to an unintentional and desirable result or because of an illness.If abortion due to rape is made an exception as a medical reason, then the criteria used as an exception must be absolutely clear and firm, so that it is not misused by irresponsible persons, consequently abortion is rife. Regarding the threat of criminal sanctions for perpetrators of provocatus abortion, in the criminal law (KUHP) it is formulated that there is a criminal threat for those who make an abortion. The Criminal Code does not care about the background or reasons for the abortion.
\end{abstract}

Keywords : abortion, medical reason, criminal law

JURNAL RECHTENS, Vol. 8, No. 2, Desember 2019 


\section{PENDAHULUAN}

\subsection{Latar Belakang Masalah}

Kehidupan merupakan suatu anugerah yang diberikan oleh Tuhan Yang Maha Esa harus dihormati oleh setiap orang. Kehidupan yang diberikan kepada setiap manusia merupakan Hak Asasi Manusia yang hanya boleh dicabut oleh pemberi kehidupan tersebut. Membahas persoalan aborsi sudah bukan merupakan rahasia umum dan hal yang tabu untuk dibicarakan. Hal ini dikarenakan aborsi yang terjadi dewasa ini sudah menjadi hal yang aktual dan peristiwanya dapat terjadi dimana-mana dan bisa saja dilakukan oleh berbagai kalangan, baik itu dilakukan secara legal ataupun dilakukan secara ilegal. Dalam memandang bagaimana kedudukan hukum aborsi di Indonesia sangat perlu dilihat kembali apa yang menjadi tujuan dari perbuatan aborsi tersebut.

Tindakan aborsi pada sejumlah kasus tertentu dapat dibenarkan apabila merupakan abortus provokatus medisinalis. Sedangkan aborsi yang digeneralisasi menjadi suatu tindak pidana lebih dikenal sebagai abortus provokatus criminalis. Aborsi itu sendiri dapat terjadi baik akibat perbuatan manusia atau (abortus provokatus) maupun karena sebab-sebab alamiah, yakni terjadi dengan sendirinya, dalam arti bukan karena perbuatan manusia (aborsi spontanus). Aborsi yang terjadi karena perbuatan manusia dapat terjadi baik karena didorong oleh alasan medis, misalnya karena wanita yang hamil menderita suatu penyakit dan untuk menyelamatkan nyawa wanita tersebut maka kandungannya harus digugurkan (abortus provokatus therapeutics atau bisa disebut aborsi therapeuticus).

\subsection{Perumusan Masalah}

Berdasarkan latar belakang yang telah dipaparkan di atas, maka per-masalahan yang akan diteliti dapat dirumuskan sebagai berikut :

1. Apakah Abortus Provocatus (tindak pidana aborsi) dapat dijadikan sebagai suatu perbuatan pidana?

2. Bagaimana bentuk perlindungan hukum terhadap korban sebagai pelaku aborsi ?

\section{METODE PENELITIAN}

Tulisan ini menggunakan metode penelitian hukum normatif, yaitu meneliti hukum dari perspektif internal dengan objek penelitiannya adalah norma hukum. Dengan kata lain penelitian hukum yang meletakkan hukum sebagai sebuah bangunan sistem norma. Sistem norma yang dimaksud adalah mengenai asas- asas, norma, kaidah dari peraturan perundangan, putusan pengadilan, perjanjian serta doktrin (ajaran). 
Pendekatan yang digunakan adalah pendekatan perundang-undangan dan pendekatan konseptual. Pendekatan perundang-undangan atau statute approach digunakan jika permasalahan penelitiannya mempermasalahkan konflik norma yang terjadi secara vertikal maupun horizontal. Dalam setiap penelitian atau survei terhadap sesuatu masalah dapatlah digunakan bermacam-macam cara atau metode seperti melakukan penelitian atau survei secara kepustakaan, melakukan interview dan sebagainya.

Pendekatan konseptual atau conceptual approach beranjak dari pandangan-pandangan dan doktrin-doktrin yang berkembang di dalam ilmu hukum, sehingga dapat menemukan ide-ide yang melahirkan pengertian-pengertian hukum, konsep-konsep hukum, dan asas-asas hukum yang relevan dengan isu yang dihadapi.

\section{HASIL DAN PEMBAHASAN}

\subsection{Abortus Provacatus (Tindak Pidana} Aborsi) Sebagai Suatu Perbuatan

\section{Pidana}

Secara istilah aborsi adalah pengguguran kandungan, keluarnya hasil konsepsi atau pembuahan sebelum waktunya. Dalam kamus Inggris Indonesia Abortion diterjemahkan dengan pengguguran kandungan. Kata Abortion dalam
Blaks's Law Dictionary, diterjemahkan menjadi aborsi dalam bahasa Indonesia mengandung arti: "The spontaneous orarticially induced expulsion of an embrio orfeatus. As used in illegal context refers to induced abortion. Dengan demikian, menurut Black's Law Dictionary, keguguran dengan keluarnya embrio atau fetus tidak semata-mata karena terjadi secara alamiah, akan tetapi juga disengaja atau terjadi karena adanya campur tangan (provokasi) manusia.

Menurut Suryono Ekotama, dkk mengatakan bahwa dari segi medis, tidak ada batasan pasti kapan kandungan bisa digugurkan. Kandungan perempuan bisa digugurkan kapan saja sepanjang ada indikasi medis untuk menggugurkan kandungan itu. Misalnya jika diketahui anak yang akan lahir mengalami cacat berat atau si ibu menderita penyakit jantung yang akan sangat berbahaya sekali untuk keselamatan jiwanya pada saat melahirkan nanti. Sekalipun janin itu sudah berusia lima bulan atau enam bulan, pertimbangan medis masih membolehkan dilakukan abortus provocatus.

Abortus Provocatus Criminalis, Adalah aborsi yang terjadi oleh karena tindakan-tindakan yang tidak legal atau tidak berdasarkan indikasi medis, sebagai contoh aborsi yang dilakukan dalam rangka melenyapkan janin sebagai akibat hubungan seksual di luar perkawinan. 
Secara umum pengertian abortus provokatus criminalis adalah suatu kelahiran dini sebelum bayi itu pada waktunya dapat hidup sendiri di luar kandungan. Pada umumnya janin yang keluar itu sudah tidak bernyawa lagi. Sedangkan secara yuridis abortus provokatus criminalis adalah setiap penghentian kehamilan sebelum hasil konsepsi dilahirkan, tanpa memperhitungkan umur bayi dalam kandungan dan janin dilahirkan dalam keadaan mati atau hidup.

Berdasarkan pengertian tersebut, pada abortus provocatus ini ada unsur kesengajaan. Artinya, suatu perbuatan atau tindakan yang dilakukan agar kandungan lahir sebelum tiba waktunya. Menurut kebiasaan maka bayi dalam kandungan seorang wanita akan lahir setelah jangka waktu 9 bulan 10 hari. Hanya dalam hal tertentu saja seorang bayi dalam kandungan dapat lahir pada saat usia kandungan baru mencapai 7 bulan ataupun 8 bulan. Dalam hal ini perbuatan aborsi ini biasanya dilakukan sebelum kandungan berusia 7 bulan. Menurut pengertian kedokteran yang dikemukakan oleh Lilien Eka Chandra, aborsi (baik keguguran maupun pengguguran kandungan) berarti terhentinya kehamilan yang terjadi di antara saat tertanamnya sel telur yang sudah (blastosit) dirahim sampai kehamilan 28 minggu. Batas 28 minggu dihitung sejak haid terakhir itu diambil karena sebelum 28 minggu, janin belum dapat hidup (viable di luar rahim).

Abortus secara medis dapat dibagi menjadi dua macam:

a. Abortus spontaneous, adalah aborsi yang terjadi dengan tidak didahului faktorfaktor mekanis ataupun medicinalis semata-mata disebabkan oleh faktor alamiah. Rustam Mochtar dalam Muhdiono menyebutkan macam- macam aborsi spontan:

b. Abortus completes, (keguguran lengkap) artinya seluruh hasil konsepsi dikeluarkan sehingga rongga rahim kosong.

c. Abortus inkopletus, (keguguran bersisa) artinya hanya ada sebagian dari hasil konsepsi yang dikeluarkan yang tertinggal adalah deci dua dan plasenta.

d. Abortus iminen, yaitu keguguran yang membakat dan akan terjadi dalam hal ini keluarnya fetus masih dapat dicegah dengan memberikan obat-obat hormonal dan anti pasmodica.

e. Missed abortion, keadan di mana janin sudah mati tetapi tetap berada dalam rahim dan tidak dikeluarkan selama dua bulan atau lebih.

f. Abortus habitulis atau keguguran berulang adalah keadaan dimana penderita mengalami keguguran berturutturut 3 kali atau lebih. 
g. Abortus infeksious dan abortus septic, adalah abortus yang disertai infeksi genital.

Kehilangan janin tidak disengaja biasanya terjadi pada kehamilan usia muda (satu sampai dengan tiga bulan). Ini dapat terjadi karena penyakit antara lain: demam; panas tinggi; ginjal TBC, Sipilis atau karena kesalahan genetik. Pada aborsi spontan tidak jarang janin keluar dalam keadaan utuh. Kadangkala kehamilan seorang wanita dapat gugur dengan sendirinya tanpa adanya suatu tindakan ataupun perbuatan yang disengaja. Hal ini sering disebut dengan "keguguran" atau aborsi spontan. Ini sering terjadi pada ibuibu yang masih hamil muda, dikarenakan suatu akibat yang tidak disengaja dan diinginkan ataupun karena suatu penyakit yang dideritanya

Istilah aborsi dalam hukum pidana di Indonesia dikenal dengan tindak pidana "Pengguguran Kandungan". Secara umum pengaturan mengenai aborsi tersebut terdapat dalam Pasal 299, 346, 347, 348, dan 349 KUHP. Pasal-pasal ini secara jelas dan tegas mengatur larangan melakukan aborsi dengan alasan apapun, termasuk aborsi karena alasan darurat (terpaksa) yaitu sebagai akibat perkosaan, baik bagi pelaku ataupun yang membantu melakukan aborsi. Bahkan dengan hukuman yang dilipatgandakan, yang membantu melakukan adalah ahli medis. Ketentuan ini terasa memberatkan terutama bagi tim medis yang melaksanakan aborsi dengan alasan medis.

\subsection{Bentuk Perlindungan Hukum Terhadap Korban Sebagai Pelaku Aborsi}

Perlindungan hukum berarti melindungi hak setiap orang untuk mendapatkan perlakuan dan perlindungan yang sama oleh hukum dan undangundang, oleh karena itu untuk setiap pelanggaran hukum yang dituduhkan padanya serta dampak yang diderita olehnya ia berhak pula untuk mendapat perlindungan dari hukum yang diperlukan sesuai dengan asas hukum. Tetapi perlu kita ketahui bahwa dalam kasus perkosaan pihak korban telah terabaikan dari jangkauan hukum. Ini terbukti dari banyaknya kasus dengan korban perempuan yang tidak mampu terselesaikan secara adil dan memuaskan.

Pengaturan aborsi provocatus di dalam KUHP yang merupakan warisan zaman belanda bertentangan dengan landasan dan politik hukum yaitu "melindungi segenap bangsa Indonesia dan untuk memajukan kesejahteran umum berdasarkan pancasila dan UUD 1945 karena melarang aborsi provocatus tanpa pengecualian". Hal ini dirasa sangat memberatkan kalangan medis yang terpaksa harus melakukan aborsi provocatus untuk menyelamatkan jiwa si ibu yang selama ini 
merupakan pengecualian diluar perundangundangan.

Contohnya adalah berlakunya Pasal 349 KUHP, jika pasal ini diterapkan secara mutlak, maka para dokter, bidan, perawat, dan tenaga medis lainnya dapat dituduh melanggar hukum dan mendapat ancaman pidana penjara. Padahal bisa saja mereka melakukan aborsi provocatus untuk menyelamatkan nyawa sang ibu. Oleh karena itu dibutuhkan untuk suatu peraturan perundang-undangan yang baru yang mengandung aspek perlindungan hukum yang tinggi bagi para tenaga medis dalam menjalankan kewajibannya. Kebutuhan akan peraturan perundang-undangan baru tersebut dipenuhi dalam Undang-Undang Nomor 36 Tahun 2009 tentang Kesehatan pengganti Undang-Undang Nomor 23 Tahun 1992.

Berdasarkan ketentuan yang terdapat dalam Undang-Undang Nomor 36 Tahun tersebut jika kita kaitkan dengan aborsi karena kehamilan tidak dikehendaki (KTD) akibat perkosaan, maka dapat disimpulkan: Pertama, secara umum praktik aborsi dilarang; Kedua, larangan terhadap praktik dikecualikan pada beberapa keadaan, kehamilan akibat perkosaan yang dapat menyebabkan trauma psikologis bagi korban perkosaan. Selain itu tindakan medis terhadap aborsi KTD akibat perkosaan hanya dapat dilakukan apabila:
(1) setelah melalui konseling dan/atau penasehatan pra tindakan dan diakhiri dengan konseling pasca tindakan yang dilakukan oleh konselor yang kompeten;

(2) dilakukan sebelum kehamilan berumur 6 (enam) minggu dihitung dari hari pertama haid terakhir, kecuali dalam hal kedaruratan medis;

(3) oleh tenaga kesehatan yang memiliki keterampilan dan kewenangan yang memiliki sertifikat yang ditetapkan oleh menteri;

(4) dengan persetujuan ibu hamil yang bersangkutan; dan

(5) penyedia layanan kesehatan yang memenuhi syarat yang ditetapkan oleh Menteri.

Apabila dihubungkan dengan aborsi karena kehamilan tidak dikehendaki (KTD) akibat perkosaan, dimana kehamilan akibat perkosaan yang dapat menyebabkan trauma psikologis bagi korban perkosaan dapat dijadikan sebagai alasan darurat (pemaksa) untuk melakukan aborsi sebenarnya perlu menjadi pertimbangan dalam menerapkan sanksi pidana, khususnya bagi para penegak hukum (Hakim). Karena janin yang diaborsi adalah sebagai akibat pemaksaan hubungan (perkosaan) dengan ancaman kekerasan.

Perkosaan sendiri merupakan tindak pidana yang pelakunya harus dijatuhi sanksi pidana penjara maksimal 12 (dua belas) 
tahun sesuai Pasal 285 KUHP. Sedangkan korbannya harus mendapat perlindungan hukum yang salah satu caranya adalah mengembalikan kondisi jiwanya akibat tekanan daya paksa dari pihak lain (tekanan psikologis). Alasan tekanan psikologis akibat perkosaan inilah yang seharusnya dapat dijadikan pertimbangan untuk menentukan bahwa aborsi akibat perkosaan sebagai suatu pengecualian, sehingga seharusnya legal dilakukan.

Arif Gosita dalam bukunya Masalah Korban Kejahatan Kumpulan Karangan mengatakan bahwa: "Dalam kasus abortus, janin ditolak sebagai makhluk hidup dan dianggap sebagai objek mati. Oleh karena diformulasikan seperti itu maka penghancurannya saat itu tidak dianggap sebagai suatu pembunuhan dan tidak menimbulkan kemarahan moral atau pertentangan moral seperti pada kasus pembunuhan lain."

Apabila dihubungkan dengan Pasal 48 KUHP tentang daya paksa (overmacht), sebenarnya Pasal 75 ayat (2) huruf b UU No. 36 Tahun 2009 yang mengatur tentang pengecualian melakukan aborsi terhadap kehamilan akibat perkosaan, mengakui adanya daya paksa bagi barang siapa yang melakukan aborsi.

Ketentuan tentang overmacht atau daya paksa yang terdapat dalam pasal 48 KUHP, yaitu : "Barangsiapa melakukan perbuatan karena pengaruh daya paksa tidak dipidana”. Dari ketentuan pasal 48 KUHP tersebut dapat disimpulkan,

"bahwa yang dimaksud dengan daya paksa adalah suatu paksaan atau tekanan yang tidak dapat dihindarkan. Adapun paksaan itu dilakukan oleh seseorang terhadap orang lain dengan suatu ancaman yang membahayakan diri dan jiwanya. Tentu saja dalam hal ini, orang yang diancam tersebut mempunyai dugaan kuat bahwa ancaman itu benar-benar akan dilaksanakan apabila ia menolak mengerjakan sesuatu yang dikehendaki pemaksa (pengancam)".

Daya paksa (overmacht) ini merupakan alasan pemaaf. Dalam alasan pemaaf ini, seseorang yang melakukan perbuatan pidana tidak dapat dijatuhi pidana karena tidak adanya kesalahan. Artinya perbuatan yang dilakukan oleh terdakwa tetap bersifat melawan hukum, jadi tetap merupakan perbuatan pidana. Tetapi ia tidak dipidana, karena tidak adanya kesalahan. Dengan demikian, alasan pemaaf adalah alasan yang menghapuskan kesalahan terdakwa. Karena overmacht sebagaimana yang tercantum dalam pasal 48 KUHP hanya memuat alasan pemaaf, artinya perbuatan yang dilakukan tetap bersifat melawan hukum, tetapi kesalahannya bisa dimaafkan karena pengaruh daya paksa tadi.

Dalam kasus abortus provokatus pada korban perkosaan terjadi konflik antara 2 (dua) hak, yakni hak perempuan yang hamil 
bertentangan dengan hak janin. Dengan demikian untuk menentukan apakah perempuan yang melakukan abortus provocatus atas kandungannya dapat dipidana atau tidak dapat dinilai darikepentingan manakah yang lebih utama. Hak janin untuk tetap hidup atau hak perempuan untuk tetap menjalankan hidupnya tanpa tekanan psikologis dan sosial.

Mencermati ketentuan yang terdapat dalam Undang-Undang No. 36 Tahun 2009 khususnya Pasal 75 ayat (2) huruf b yang mengatur tentang aborsi karena alasan darurat (pemaksa) dalam hal ini adalah adanya trauma psikologis yang dialami oleh wanita hamil sebagai akibat tindak pidana perkosaan yang dialaminya. Pada akhirnya penyelesaian kasus tersebut sangat tergantung pada para penegak hukum untuk menegakkan keadilan terutama bagi perempuan yang jelas-jelas berkedudukan sebagai korban perkosaan.

Apabila aborsi karena perkosaan dijadikan pengecualian sebagaimana alasan medis, maka kriteria yang dijadikan pengecualian harus benar-benar jelas dan tegas, sehingga tidak disalahgunakan oleh oknum yang tidak bertanggung jawab, akibatnya aborsi marak dilakukan. Dengan demikian Undang-Undang Nomor 36 Tahun 2009 Tentang Kesehatan memperbolehkan praktik aborsi terhadap kehamilan akibat perkosaan dengan persyaratan dilakukan oleh tenaga yang kompeten, dan memenuhi ketentuan agama dan perundang-undangan yang berlaku.

Mengenai ancaman sanksi pidana bagi pelaku abortus provocatus, dalam hukum pidana (KUHP) dirumuskan adanya ancaman pidana bagi mereka yang melakukan pengguguran kandungan. KUHP tidak memperdulikan latar belakang atau alasan dilakukannya pengguguran kandungan itu. Dengan demikian, apabila abortus provocatus adalah pilihan yang harus diambil dan dilakukan oleh perempuan korban perkosaan, baik atas permintaan dirisendiri maupun melalui bantuan orang lain atas persetujuan ataupun tanpa persetujuan perempuan korban perkosaan, maka dengan menggunakan ketentuan KUHP, perempuan korban perkosaan tidak dapat lepas dari jeratan hukum, sehingga KUHP tidak memberikan perlindungan hukum terhadap perempuan korban perkosaan yang melakukan abortus provocatus.

\section{KESIMPULAN}

1. Aborsi adalah pengguguran kandungan, keluarnya hasil konsepsi atau pembuahan sebelum waktunya. Kehilangan janin tidak disengaja biasanya terjadi pada kehamilan usia muda (satu sampai dengan tiga bulan). Ini dapat terjadi karena penyakit antara lain: demam; 
panas tinggi; ginjal TBC, Sipilis atau karena kesalahan genetik. Pada aborsi spontan tidak jarang janin keluar dalam keadaan utuh. Kadangkala kehamilan seorang wanita dapat gugur dengan sendirinya tanpa adanya suatu tindakan ataupun perbuatan yang disengaja. Hal ini sering disebut dengan "keguguran" atau aborsi spontan. Ini sering terjadi pada ibu-ibu yang masih hamil muda, dikarenakan suatu akibat yang tidak disengaja dan diinginkan ataupun karena suatu penyakit yang dideritanya.

2. Apabila aborsi karena perkosaan dijadikan pengecualian sebagaimana alasan medis, maka kriteria yang dijadikan pengecualian harus benar-benar jelas dan tegas, sehingga tidak disalahgunakan oleh oknum yang tidak bertanggung jawab, akibatnya aborsi marak dilakukan. Dengan demikian Undang-Undang Nomor 36 Tahun 2009 tentang Kesehatan memperbolehkan praktik aborsi terhadap kehamilan akibat perkosaan dengan persyaratan dilakukan oleh tenaga yang kompeten, dan memenuhi ketentuan agama dan perundang-undangan yang berlaku. Mengenai ancaman sanksi pidana bagi pelaku abortus provocatus, dalam hukum pidana (KUHP) dirumuskan adanya ancaman pidana bagi mereka yang melakukan pengguguran kandungan. KUHP tidak memperdulikan latar belakang atau alasan dilakukannya pengguguran kandungan itu.

\section{DAFTAR PUSTAKA}

Arif Gosita, Masalah Korban Kejahatan, Kumpulan Karangan, Jakarta, Akademika Persindo, 1985

Echols dan Hasan Shaddily, Kamus Inggris Indonesia, Jakarta ; Gramedia, 1992,

Henry Campbell Black's Law Dictionary, Sixth Edition, St. Paul Min West Publishing Co

I Made Pasek Diantha, 2016, Metodologi Penelitian Hukum Normatif dalam Justifikasi Teori Hukum (Jakarta : Prenada Media Grup

Terjemahan Abortion menurut Black's Law Dictionary, diambil dari Suryono Ekotama, dkk., Abortus Provokatus Bagi Korban Perkosaan Perspektif Iktimologi, Kriminologi dan Hukum Pidana, Yogyakarta, Universitas Atmajaya, 2001

Rustam Mochtar dalam Muhdiono, Aborsi Menurut Hukum Islam, "Perbandingan Madzhab Syafi'i dan Hanafi”, Skripsi, Yogyakarta, UIN, 2002 
Sri Setyowati, Masalah Abortus Kriminalis di Indonesia dan Hubungannya dengan Keluarga Berencana Ditinjau dari Kitab Undang-Undang Hukum Pidana, Jakarta, TP, 2002

Yayasan Pengembangan Pedesaan, Kesehatan Reproduksi, cetakan 1, Malang, Danar Wijaya, 1997,

\section{Peraturan Perundang-undangan :}

- Undang-Undang Dasar 1945 ;

- Kitab Undang- Undang Hukum Pidana;

- Undang-Undang Nomor 23 Tahun 1992 dirubah menjadi Undang-Undang No. 36 Tahun 2009 tentang Kesehatan

\section{Internet}

Erwin Yuliatiningsih, "Kebutuhan

Perlindungan Hukum Bagi Perempuan Tindak Pidana Perkosaan di Indonesia" http://www/google.com, diakses tanggal 3 Desember 2019

\section{BIODATA SINGKAT PENULIS}

Rini Wulandari lahir di Jember, 20-121993. Menyelesaikan Pendidikan S1 Ilmu Hukum pada Fakultas Hukum, Universitas Wijaya Kusuma Surabaya tahun 2016. Pada saat ini tengah menyelesaikan program Magister Hukum, di Universitas Narotama, Surabaya 